\title{
ヒト歯肉由来悪性黒色䏸培誉細胞に関する実臨的研究
}

\author{
田川俊 郎
}

\section{Experimental studies on cultured cells of malignant melanoma in human gingiva}

\author{
Toshirou TAgawa
}

\section{I. 緒}

ヒト悪性腫痃の組樴培着の試みは，古くは Carrel, Burrow (1911)"の線維軟骨陣に始まるといわれている か;, Gey ら $(1952)^{2)}$ の HeLa 細胞株の確立が今日の 卜悪性腫㻛培養法を急速に進展させた。

その後, 培養技術, 器材, 抗生物質, 培養液等の進歩 改良に伴い，1960年頃から組織培着法は着実に発展して いる.

悪性腫湯の組織培養は，腫湯細胞分化の研究，放射線

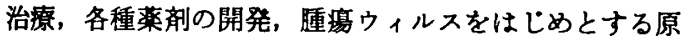

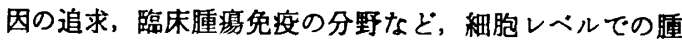
場研究のあらゆる領域に利用されている。

特に一定の增殖を維持する細胞株の樹立は，in vitro での再現性のある実験資料を随時提供する点で意義深 い.しかし株化に至るまでの経過は長く, 種々の要因に よりかなりの困難を伴らことが多い。なかでもとト悪性 尰堨の培養, 株化は難しいとされている3゙.

このように組織培養は，きわめて有用な研究法である か，培養条件が in vivo と異なるために，細胞の機能や 状熊が必ずしす in vivo の状況を再現しているとはいい がたい，この欠点を解決する手段として，生体内培養が あり, 同種の細胞についてはよく用いられている。しか しこの方法では，ヒト由来 in vitro 系細胞または臨床材 料に応用するのは不可能かあるいは各種の前処㯰を必要 とする。

ヌードマウスは Flanagan (1966)4) が発見し, Pantelouris $(1968)^{5)}$ により胸腺の欠損が指摘された突然変異 種でこの免度不全状態が種々の研究に用いられてい る.なかでも Rygaard と Povlsen (1969)6)が最初にヒト 癌の移植に成功して以来, 幅広く利用されている.

以上述へてきたごとく，目的とする腫易細胞を in vitro

三重大学医学部口腔外科学教室（主任：村田睦男教

授)

Department of Oral Surgery, School of Medicine,

Mie University (Chief: Prof. Mutsuo Murata)

受付日 : 昭和56年 2 月 16 日
あるいは in vivo で株化させ得るならば，多くの知見を すたらすと考えられる。

覀性黑色腫よりの細胞培莨は，古くはTakano (1929) $)^{7}$ によって試みられている。 またその臨床所見から本腫瘍 の細胞培苃は，容易であろらと考えられているが，以後 多くの研究者が各種の培養法を応用して細胞学的側面を とらえているにもかかわらず，これらの多くは，一時的 初代培簒で短期間の観察に止まり，継代系培養細胞株之 して報告され，かつ in vitro されている例は少ない.

一方口腔領㳦由来黑色睡の細胞培湌については， Brown (1968) ${ }^{8)}$ が最初に報告し，結城9) らの報告むある が，いずれる10世代内外あるいは初代培鋃細胞に関する あののみで，株化されるに至っていない．

著者はすでに，上額前歯部霜肉原発の黒色腫症例で， 転移が確認された胸水中細胞の初期培養所見について報 告した ${ }^{10)}$ その後株化を試み，現在まで，初代培養以後 2 年半経過し，継代数は 130 代を越え株化樹立したと判 定した. さらに前述の観点からヌードマウスへの移植お よび形成された腫痦，腹水からの細胞培善，累代移植な どを行いヒト歯肉由来悪性黑色稙の in vitro $冖$ in vivo 実 験系の確立を図った。

\section{II. 実験材料ならびに実験方法}

\section{第 1 项 細胞培謷}

(1) 培养材料

すでに報告した ${ }^{10)} 59$ 歳男性で，左側上顯前雪部に原発 巣を有する悪性黒色腫末期患者の胸水から採取した細胞 を培着材料とした，対照として59歳男性で，下顎骨骨折 症例に胁骨骨折を合併し, 胸水眝溜が钼察された例，お よび55歳女性で乳癌末期に胸水詝溜をきたしたそれぞれ の胸水を採取し，黒色腫症例と同様の方法で培養を行っ た.

（2）培養液

Eagle's MEM (阪大微研, Penicillin G 100 Unit, 硫 酸 Streptomycin $100 \mathrm{mg} / \mathrm{l}$ 含有) および RPMI 1640 （GIBCO 社）飞牛胎児血清（GIBCO 社）を $20 \%$ の割 
合に含有させ $\mathrm{pH} 7.3 〜 7.5$ に調整して优川した。

(3) 培塑法

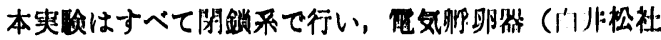

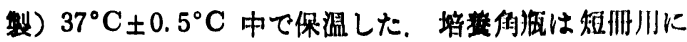
小型，粎代用に大四角 (池本理科社製)，MA 30 (ファ

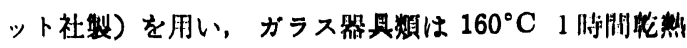
減菌、シリコーンコム栓は $120^{\circ} \mathrm{C} 1.2$ 気压で 45 分湖就 王波菌した。

\section{(1) 面裉培䖭}

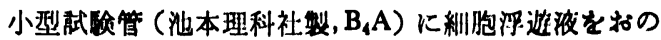

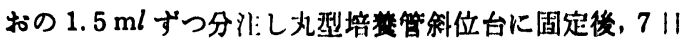
間の增殖度を测定した，細胞数の算远は、おののの 3 本 の試険管を任意に抽出し，0.25\%トリブシン(阪人微研) で細胞を単離（単離率 95\% 以上)，Burker-Turk 血球計 算板を用いて，1 本につき 3 回全細胞数を数え平均值を とった。

(2) 旋回培羕

旋回培鉒 (Gyrotory shaker, Model $\mathrm{G}_{2}$, New- Brunswick 社製）を使用し，細胞数 $1 \sim 9 \times 10^{5} / \mathrm{ml}$ を三角 ラスコ(Pyrex 社製, $20 \mathrm{ml}$ ) K $4 \mathrm{ml}$ ずつ分注後, 回転 数 $75 \mathrm{rpm} / \mathrm{min}$. で細胞塊を形成させた。

(4) 形態学的観察法

(1) 光䫒観察

培湌全経過を通じて，主として倒立位相差影微鏡によ り, 逐次細胞形態, 細胞集団の增殖様式を锶察記録する とともに，適時短冊培羪 し， H-E 染色，Jacobson 染 色 ${ }^{11)}$, Dopa 反応 (Fitzpatrick 法) ${ }^{12)}$, Combed DopaPremelanin 反応 ${ }^{13)}$ を行い検鏡樭察した。

(2) 電䫒観察

培養液交換後，培養梄底面に付着している 細胞を 5.4 \%庶糖加リン酸㣪衙夜で洗浄し， $2.5 \%$ クルタールフル デヒドで 1 時間 1 次固定, 上記洗浄液で洗浄後, $1 \%$ オ スミウム酸で 1 時間 2 次固定した. 次いでラバークリー ナーで細胞を划し，1,000 回転 10分間遠沈後, 細胞塊を 形成させた. 包埋はェタノール采列による脱水後, Epon 火包埋, 重合は $60^{\circ} \mathrm{C} て ゙ 48 〜 72$ 時間行い, 超薄切片を作 製した。 ウラニールアセテート，酢酸鉛にて重染色を施 した後, 検鏡観察, 写真撮影を行った。

（5）染色体標本作製法

標本作製の前日に培養液を交換し, 翌日 $4 \mu \mathrm{g} / \mathrm{m} l$ の二 ルセミド (SIGMA 社製) を含む培養液に交換後，6〜 8 時間培養, 低張液 $(0.075 \mathrm{MKcl})$ 処理を行い, カル フ夜にて固定後, 速やかに乾燥した。次いで Macllvain 㣪衙液にて標本を洗浄し $50 \mu \mathrm{g} / \mathrm{ml}$ Quinacrine mustard dihydrochloride (SIGMA 社製) 染色液で15分間染色, 流水で軽く洗い, 湲衝液 I， I， II におのおの通し，力 ハーークララスをかけ, 罃光顕微鏡下で観察, 写真撮影し た.

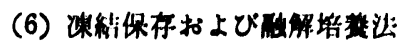

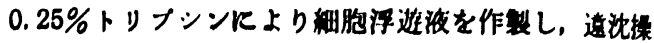
作にてトリブンンを除志，継代培独派に 10\% Dimethyl sulfoxide, DMSO (和光純浆) を添加した㳊で，1〜2x

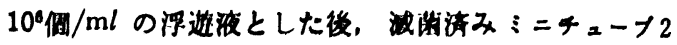
$\mathrm{ml}$ (WHEATON 社製) $\mathrm{k} 1 \mathrm{ml}$ 广゙分注L $0^{\circ} \mathrm{C} \mathrm{30}$ 分, $-20^{\circ} \mathrm{C} 60$ 分, $-80^{\circ} \mathrm{C} 120$ 分と的次移し $-196^{\circ} \mathrm{C}$ (花体

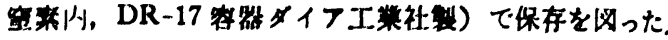

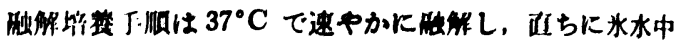

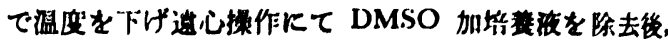
従米の培地を加え24㭙阙後に再度培地の交缜を行った。

\section{第2项 ヌートマウスへの移柱}

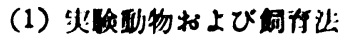

BALB/c（nu/nu）の遭伝子背是を有する スードマウ ス (日本クレフ社) を用い，本学物物センター内（室得 $25 \pm 2^{\circ} \mathrm{C}$, 湿度 $35 \pm 5 \%$ ) の Laminar flow Iso-Rack 中 で铜青した。 ケージおよび給水器はポリカーポネイト

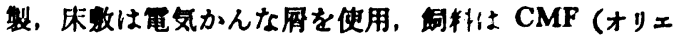
ンタル醉母社製)，钦料水は水道水をそれぞれ自由职取 として給与した。 なおケージおよひ床数は20分间，本道

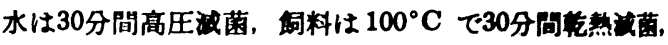
また飼育器具は週 1 回交換，管理は可及的下，寒険摷作 はすべて無菌的に行った。

（2）移植材料および方法

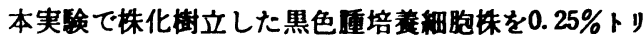
ブシンにより分散後，遠沈操作にてトリブシンを除去, PBS (-) Kて 2 3 回洗浄後皮内反底用注射筒に19G 針をつけ，腹腔内および背部皮下に注入した。

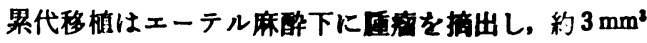
の小片に細切後癌細胞移植針（径 $3.5 \mathrm{~mm} \times 9.5 \mathrm{~mm}$, 日 本クレア社製）にて背部皮下のみに移植，刢部はミシェ ルのクリップにより閴した。

(3) 形成腫售测定法

移植後形成された尰慮は释時的に愊 ( $\mathrm{a} \mathrm{mm})$, 長さ （b mm）をスライドキ+リバーで湘定し $w=\frac{a^{2} \times b}{2}(w$ $=\mathrm{mg})^{14)}$ の式に代入し重量として換算した．体重娜定は マウス天科（日本クレア CL 4501）にて测定した.

(4) 形態学的钼察法

(1) 光䫒観察

通法に従い10\%ホルマリン固定绕，H-E 染色し梌鏡 観察した。 また Dopa 反応 (Fitzpatrick 法) b部時行 った.

\section{(2) 電䫒観察}

形成された腫瘦の辺緑部を資料として採取後，直ちに $5.4 \%$ 庶糖加クエン酸枟衝液で 2 ないし数回洗浄， $2.5 \%$ グルタールアルデヒドにて 2 時間 1 次固定を行った．同 様の楥衝液で 3 時間洗浄し，1\%オスミウム酸で 1 時間 2 次固定, 洗浄後了ルコールフセトン系列で脱水, Epon 包埋は $60^{\circ} \mathrm{C}$ で48〜72時間行い，以下通法に従い超薄切 
片を作製し，ウラニールアセテート，酷酸鉛にて![染色 を施した後，柣鏡写真振影した。

第了項 ヌードマウスに形成された琏病および腹水の 培䔄

(1) 培塊材料

培善材料は，MEM で継代を持続した細胞株（50代） をヌードマウスに移植後 10 週めの隀嘴およひ RPMI 1640で維持してきた細胞株（50代）移植後10週めの腹水 である.

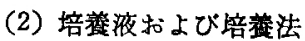

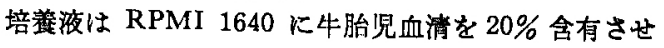

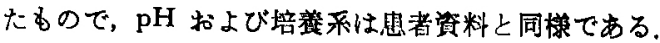

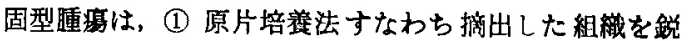
利なメスで $1 \mathrm{~mm}^{3}$ の小片に細切し，PBS (+)にて洗

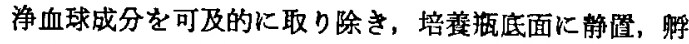
卵器中に放固啳原片が浮遊しないように静かに培盖液を 加える万法と，(2) 細切した組織片をPBS（一)にて洗 浄後，0.25\%トリブシンおよびマグネチックスターラー にて化学的, 機械的に分散し, 白金製細胞榩過器 よび \$150（池本理化社製）を通し均一な細胞浮遊液とし た後，初代培盖を開始した，腹水よりの培善は先に報告 した方法 ${ }^{10)}$ と同様に，腹水を培着液中に $1 / 2$ 残すよらに 調整後開始した。

\section{III. 成}

績

\section{第 1 項 細胞培養}

(1) 培養経過

初代培養は，1978年 5 月17日に行い10日後に培養液の 半量を交換し，最初の継代は 1 か月後に施行した。この 時点で RPMI 1640 液を MEM と同時に使用し, 以後 並行して稚持している．継代はPBS (+) で洗浄後ラハ 一ポリスマンまたは0.25\%トリプシンで培着瓶底面より 細胞を剝離， 2 瓶に分割する手順で行っている，培養液 交换は，初期 1 年間は週 2 回としていたか，現在は週 1 回の割合で行っている(表 1).MEM 群と RPMI 群 の柈保作時に認められた差は，RPMI 群が機械的， 化学的ともに剝離分散されやすい点であり，両群ともに 約15分で培養瓶底面に付着する. 途中細菌, 真菌等の感 染により 2 ・3の培体を失ったが，現在 (1980年11月13 日) MEM 群， RPMI 群ともに 130 代に達しなおよく 增殖を絽り返している。

(2) 光䫒所見

(1) 黒色腫よりの所見

細胞形態は，一般的に紡錘形および多角形上皮様細胞 からなるが，円形，扇子状，長三角形など，多種多様に 表現しうる形を示し特に円形の細胞はメラニンと思われ る顆粒を有しているのが散見された，培養初期にはこれ ら各種形態を有する細胞が混在していたが，継代を重ね

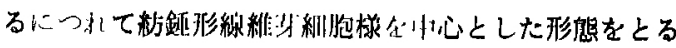

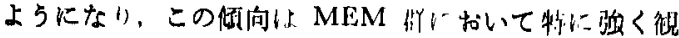

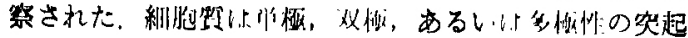
を有して占り，その先端の多くは㤔であった，双殹性

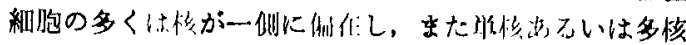

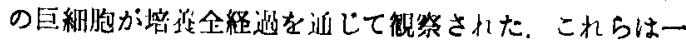

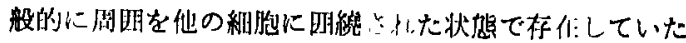

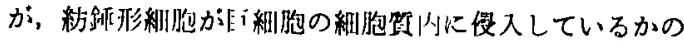

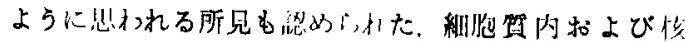

表 1 牌程遇

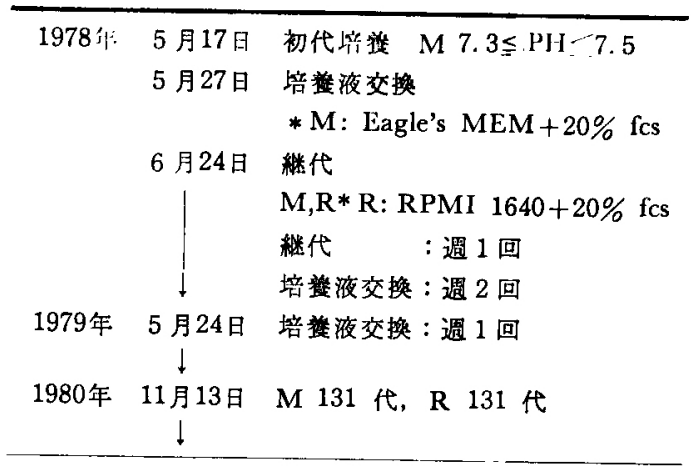

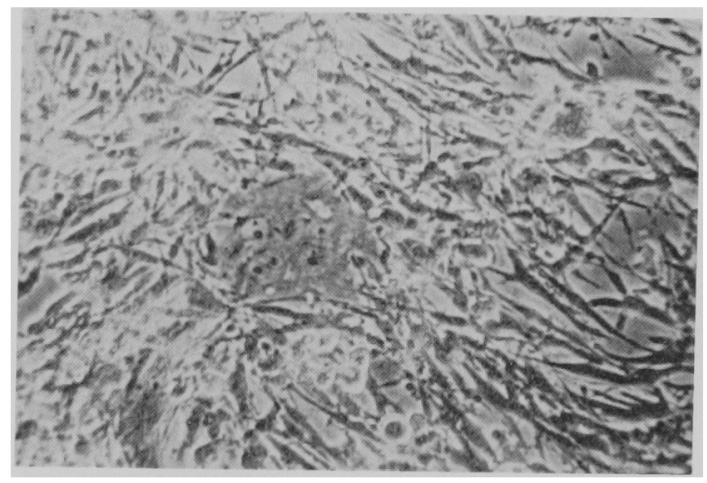

写真 1 位相差像 3 代 $(\times 200)$

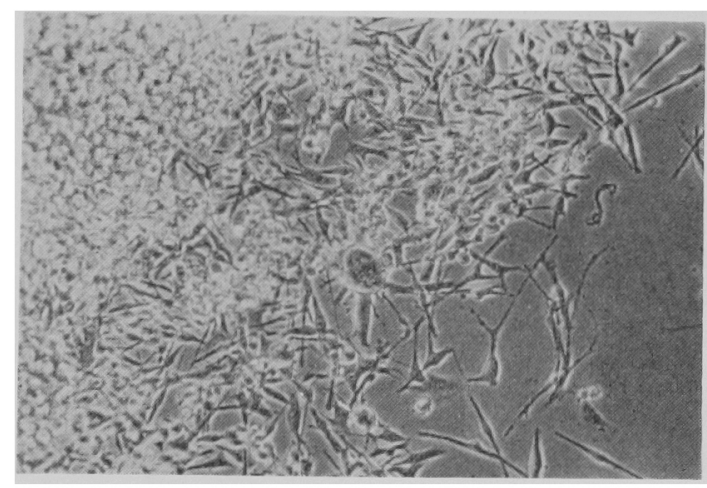

写真 2 位相差像 36 代 $(\times 100)$ 


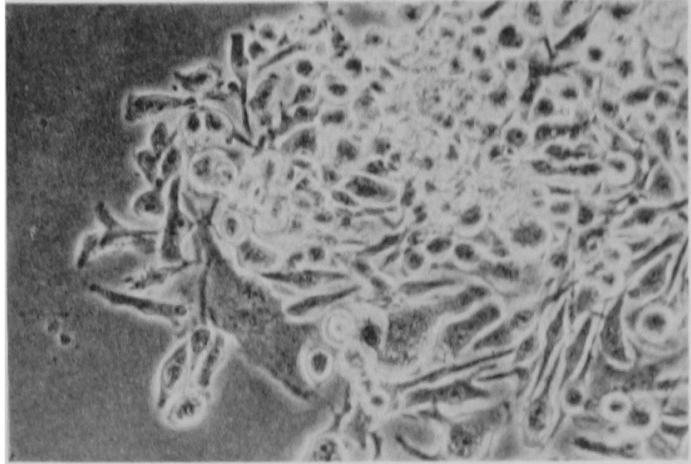

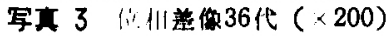

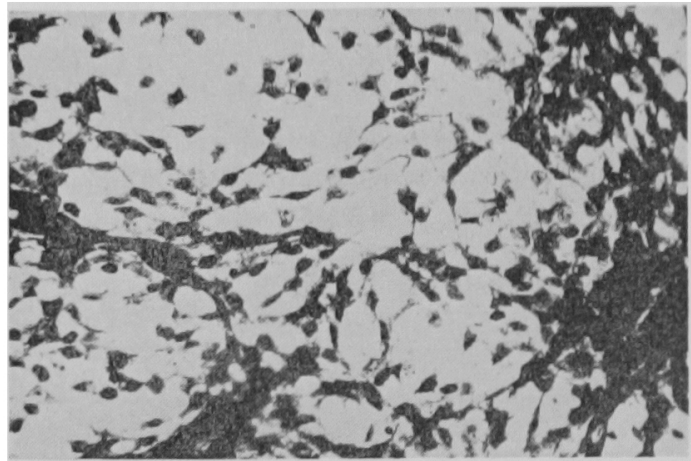

写重 5120 代 (Combed Dopa-Premelanin 染色, $\times 200)$

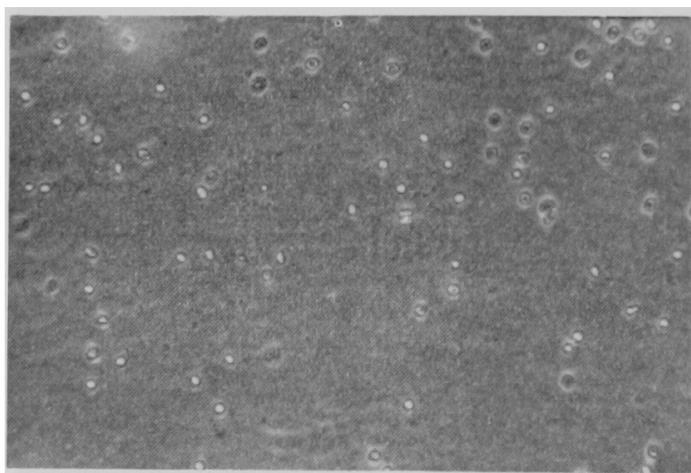

写声 7 位相差像 $(\times 100)$

内には Jacobson 染色, Dopa 反応, Combed DopaPremelanin 反応においてもメラニンと思われる顆粒は 明確に钼察されなかった，核は円形または邸円形で，そ の辺縁は比較的平滑であり 2 ないし数個の明確な仁を有 している.

増殖様式は個々の細胞かi criss cross しあい, contact inhibition の欠如が多数観察された。 またこれらが重な りあってブドウの房状集塊を形成するコロニー様増殖と

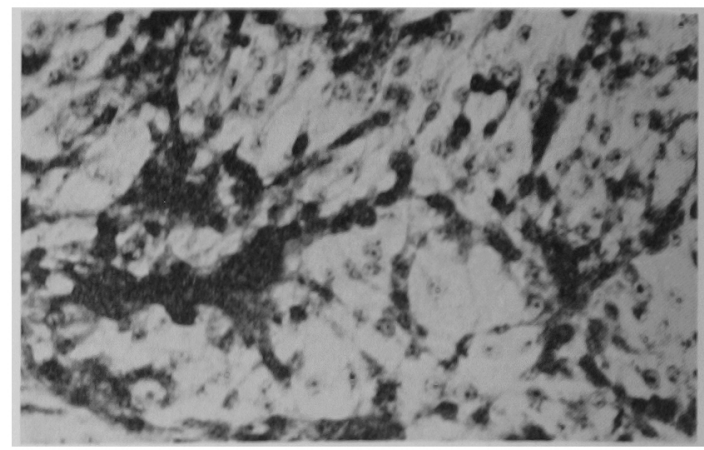

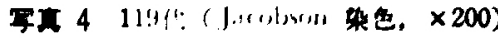

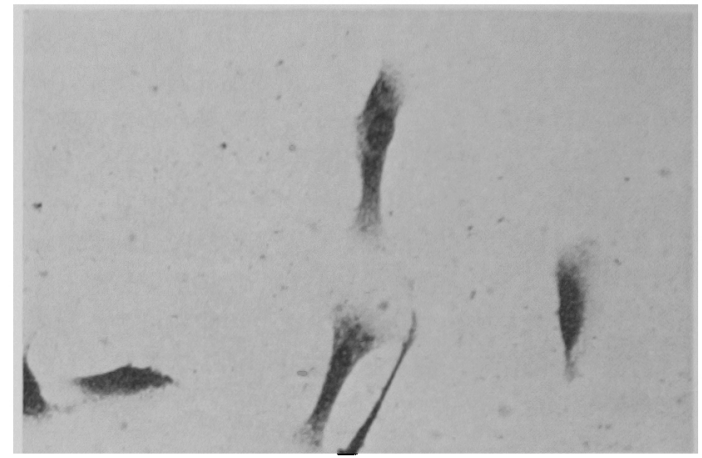

写卉 6 (Jacobson 染色， ×200)

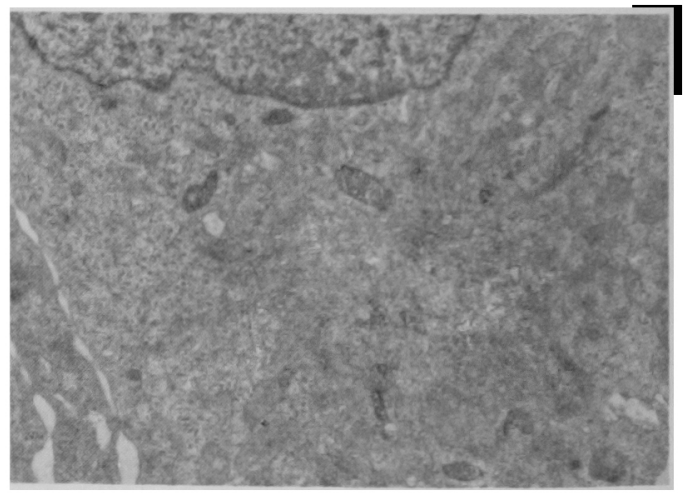

军啹 8 電踑像 $(\times 20,000)$

その周囲への避出を繰り返しており，均一な単首状には ならない(写南1〜5).

(2) 対照例よりの所見

i ）肋骨骨折から胸水貯溜をきたした在例の培養所見 では，少数の線維芽細胞様細胞の培着底面人の付着が 認められたのみで，秤代されるに至らなかった，肎直 6 は 1 週間めの光顕像である.

ii）乳癌患者からの例では，血球成分のみで上皮様あ るいは線維芽細胞様細胞の付着増殖は観察されなかっ 


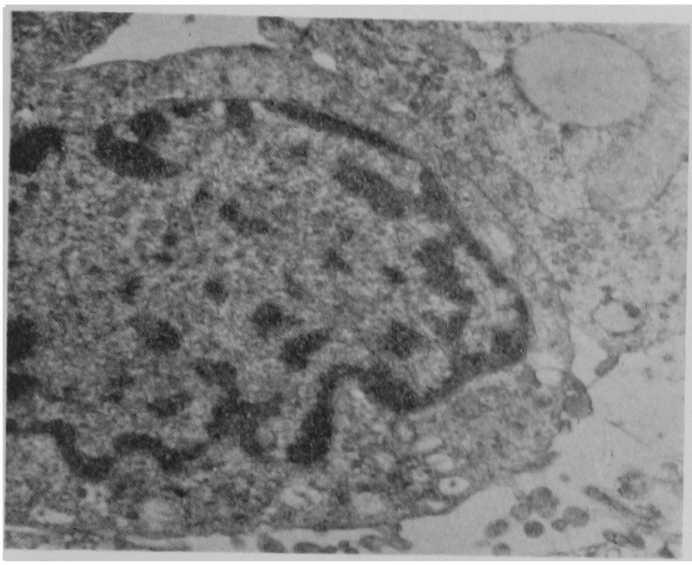

写重 9 電蝢像 $(\times 10,000)$

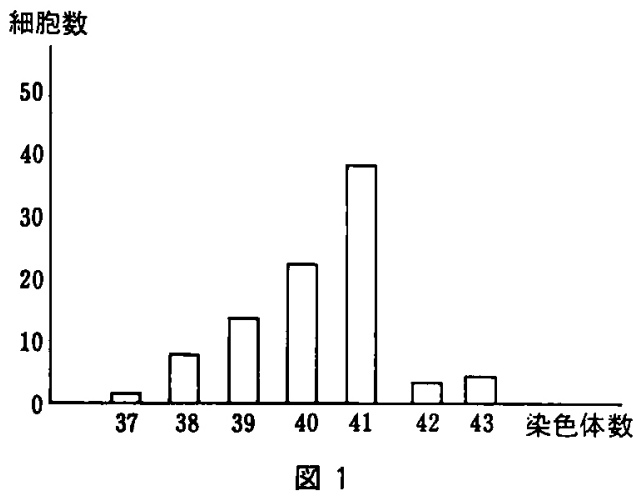

た. 写真 $7 は 1$ 週間めの位相差像である。

(3) 電顕所見

以上述べてきたように稩胞群は腫煌性の増殖様式を示 すが，光顕的にはメラニン顆粒は確認されなかったの で,さらに電顕観察を行った。

写真 8 は初代培養細胞の電湿像で，ゴルジ装䈯が 2 か 所にみられ，Toda ${ }^{15)}$ の分類による Stage II， II あるい はVの Premelanosome が認められる。核膜は凹凸不整 でクロマチンは不均等に分布している。また各細胸間に はデスモゾームによる結合方式は認められない，

写直 9 は26代めの細胞であり，細胞質内にはStage I またはIIの Premelanosome が観察されるのみで, 継代 に伴って melanosome 形成能の低下がうかがわれる所 見を呈している。

（4）染色体所見

図 1 は 3 代めの分裂中期細胞 100 個についてその染色 体数を調べたすので，数は37〜43の間に分布しモードは 41を示している，写真10はQバンドバターンでいくつか の異常染色体が観察され，強い營光を発するY染色体の 存在は，本細胞群は男性由来であることを示している。

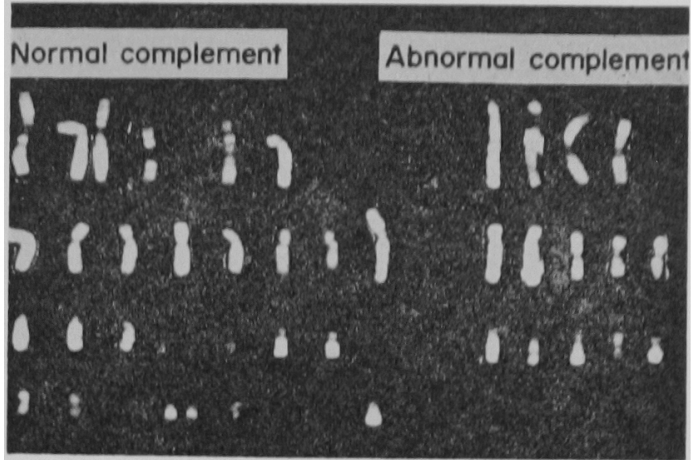

写陑 10

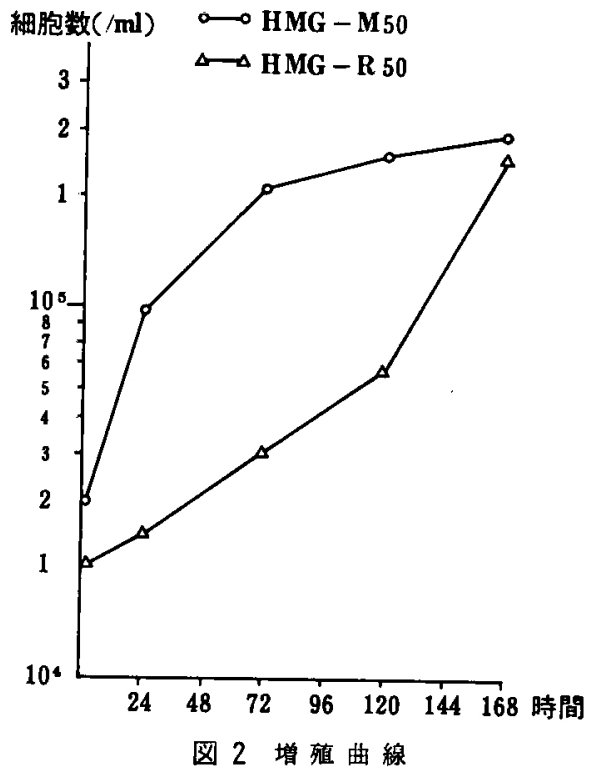

（5）増殖曲線

MEM および RPMI 群で50代めについて，同一ロッ トの血清を使用して重複培養法により增殖曲線を求め た. 1 週間の経時的推移は图 2 のごとくで，片対数ダラ フにプロットしたものである，MEM 群では，24時間 後 $9.8 \times 10^{4}$ 個, 72 時間後 $11.2 \times 10^{4}$ 個, 120 時間後 15.2 $\times 10^{4}$ 個, 168 時間後 $20.0 \times 10^{4}$ 個であり Doubling time は 68.5 時間であった，RPMI 群では，それぞれ $1.4 \times 10^{4}$

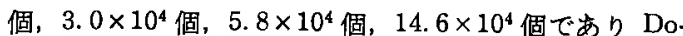
ubling time は50.0時間を示していた。これらの結果を クララフ上から镜察すると，MEM 群では 2 日め頃より 增殖度が強くなり 1 週間後にはプラトーに達しつつある 所見を示しているが， RPMI 群では5日め頃より增殖 が強くなりその後 1 週間を释てもな扰よく增殖する傾向 にある(図 2). 


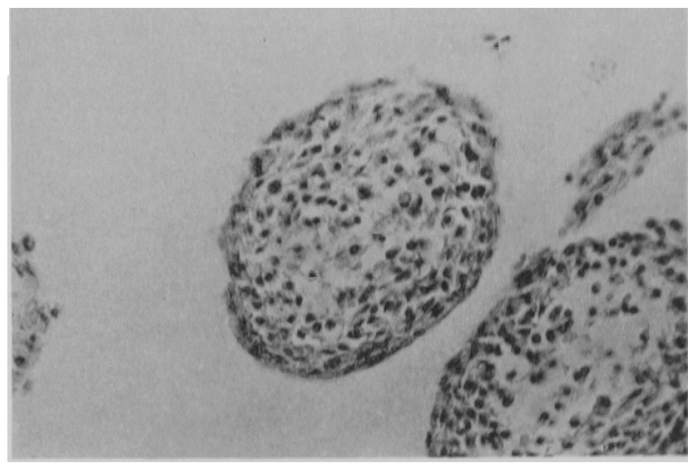

军两 11 (11-1; 架色， $\times 100 ）$

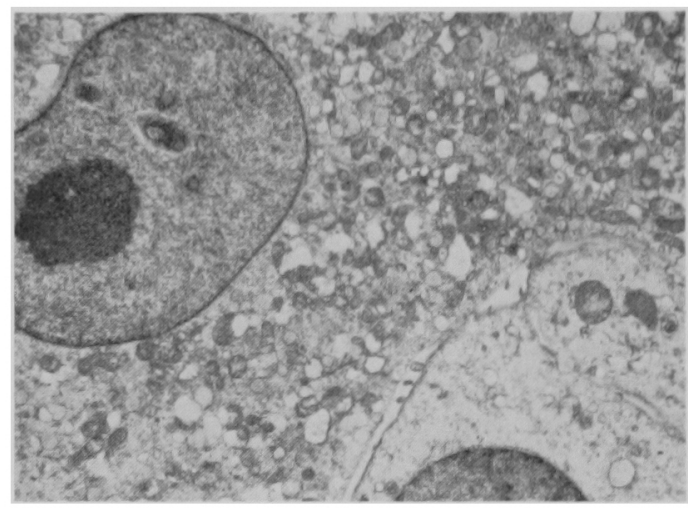

写亲 12 電影像 $(\times 10,000)$

(6) 旋回培賈所見

旋回培養時に形成される細胞集塊は，球形あるいは長 棈円形であり，表面は凸凹不整で本細胞群を静置した場 合に観察されるコロニー様細胞集塊に類似しており，約 1 週間で $1 \mathrm{~mm}$ 前後の径となる。ささらに本培堢法を持続 すると細胞集塊の大きさは縮小する.

MEM 群, RPMI 群ともに93代めを単離し細胞数 1 $\times 10^{5} / \mathrm{m} l$ として， 1 週間旋回培養後に形成された細胞 塊数は， $25 \mu l$ 中それぞれ15個扰よび 3 個であり MEM 群の集塊形成能の強さを示していた，写真 11 は MEM 群の光顕所見で, 各細胞間の結合は粗で中心部は壊死に 陥っており，管腔形成等の特異的所見は認められない．

写真12は同様に93代（MEM）の1週間後の旋回培養細 胞の電顕所見であるか， 細胞質内には Stage II， II の Premelanosome が認められ円形を呈するミトコンドリ アが稩胞質全体に分布し細胞機能の活発さを示しまた多 数の空胞も観察される．核は円形で，大きな仁および核 内封入体がるられクロマチンは均等に分布している.

(7) 凍結融解後の所見

形態学的あるいは増殖様式ともに融解前と同様であり 変化は認めなかった.

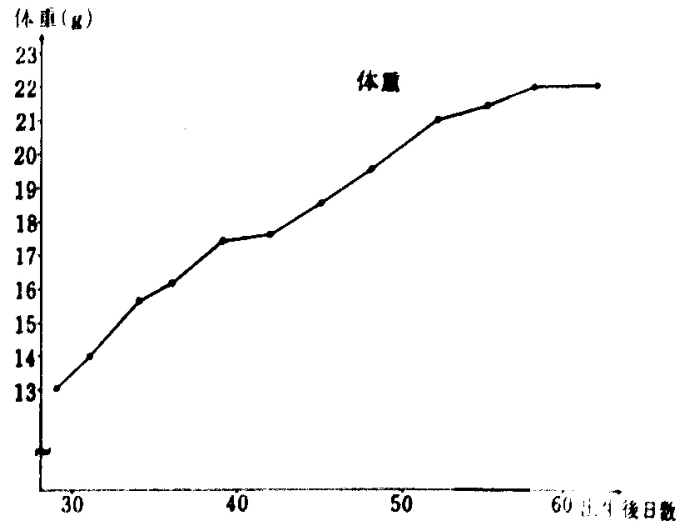

因 3

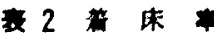

\begin{tabular}{|c|c|c|c|}
\hline & HMIr; 1185 & HMG-R85 & HMSinu-7 \\
\hline 皮 下 & $5 / 6$ & $1 / 6$ & $4 / 5$ \\
\hline 盟空内 & $6 / 6$ & $2 / 6$ & $4 / 5$ \\
\hline st & $6 / 6$ & 26 & $5 / 5$ \\
\hline
\end{tabular}

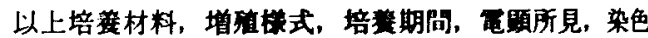

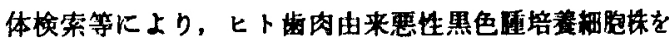
樹立したと判定した。本細胞㧣の名称を Human Mal ignant Melanoma from Gingiva の頭文字をとって $\mathrm{H}$ NG と命名した，以下 HMG と略記し，HMG-M15 は

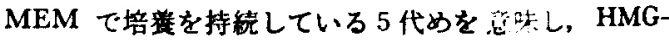
R10 は RPMI での10 代めを意味する。 また培䔔操作 上，旋回培管所見などから HMG-R 群がりり本来の形 質を保持していると思われた。

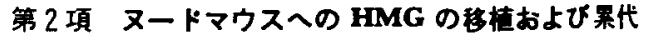
本実匼で化された HMG にin vivo て重演形成能

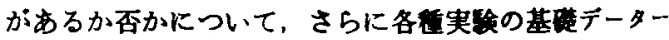
を得る目的で $2 \sim 3$ の検討を加えた。

(1) 体 重

図3は本学動物センター内での未処動ヌードマウス7 匹の体重平均值を経時的に示したりので，安定した成長 発育がみられ，8週頃より $22.0 \mathrm{~g}$ 前後の值をとるよら になる。 また Wasting Syndrome で死亡する例忙 Laminar flow Iso-Rack 中では観察されなかった。

(2) HMG のヌードマゥスへの移植

HMG-M55,-R55をそれぞれ細胞数 $1 \times 10^{6}$ 個，6〜8 週龄のヌードマウス背部皮下および腹腔内に注入した. 約10週後に MEM 群については3 頭中 1 頭に重㽷形成 のみが，一方 RPMI 群では 3 頭中 1 頭に腹水の詝溜の みが観察された，次いで，HMG-M85，HMG-R85 を 5 週龄ヌードマウスのおのおの 6 頭に $1 \times 10^{6}$ 個ずつ, 
背部皮下および腹腔内に注入した。兩群とるに倣水化は みられず，腹腔内では固型の陳瘤として器青する栏式が 钼察された。着床率は表 2 に示すよらに MEM 群 100 \%，RPMI 群 $33.3 \%$ であった，一般的に腫痛形成の有 無が触診により確認し5る大きさは， $3 \mathrm{~mm} \times 3 \mathrm{~mm}$ (13. $5 \mathrm{mg})$ 以上でありこの大きさに達するまでには平均 64日を必要とし，安定した增殖を示すまでには86日(146 $\pm 14.4 \mathrm{mg}$ ) を要し，その後順調に発育し，106日で66.0 土19.3 mg となる(图 4).

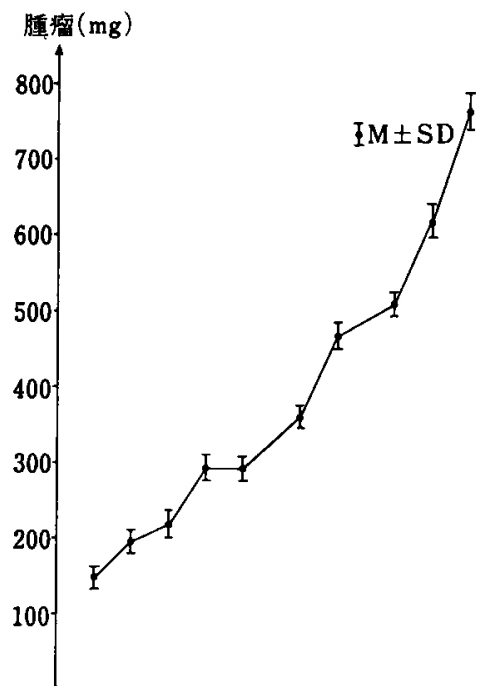

$8 6 \longdiv { 8 8 9 0 9 2 } 9 4 \quad 9 7 9 9 \quad 1 0 2 1 0 4 1 0 6$ 移植後日数

図 4 HMG-M85 の移植
(3) 婴代移梢i

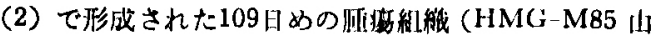

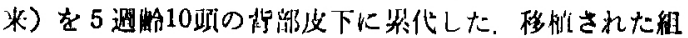

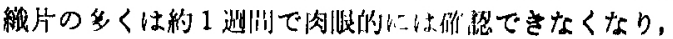

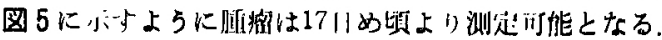

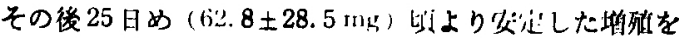
小古よらになる。休们は移㮩後17日めから1911めにかけ

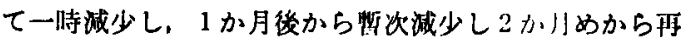

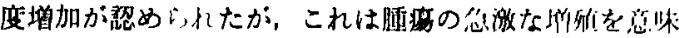

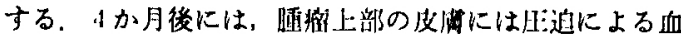

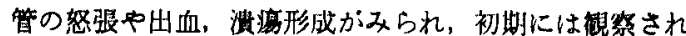

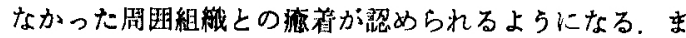

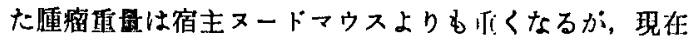
までのところ枟移形成は確認していない，形成された腫 瘤は灰白色で，分葉状の発育をし，割面は中心部で出血

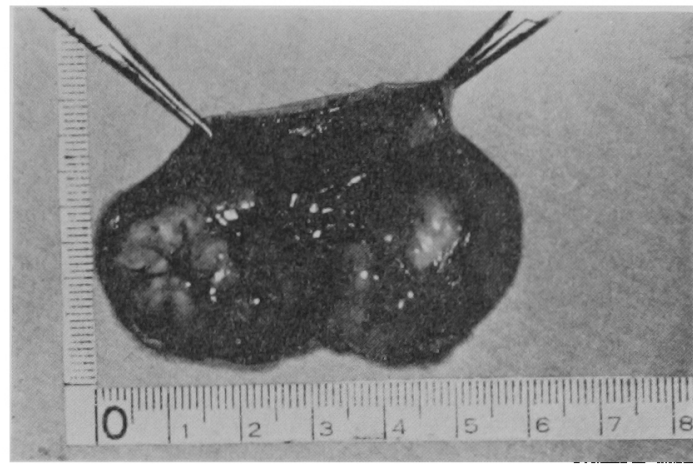

写直 13 摘出腫瘍（移植後131日）

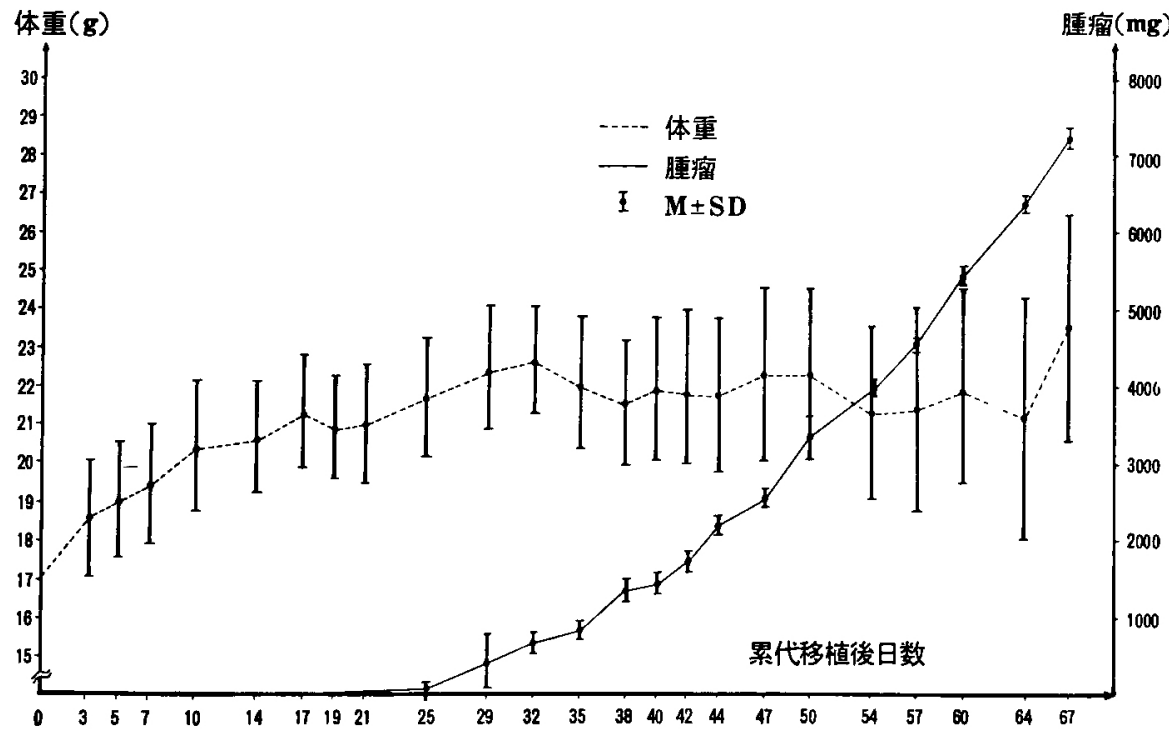

图 5 噤代移植 


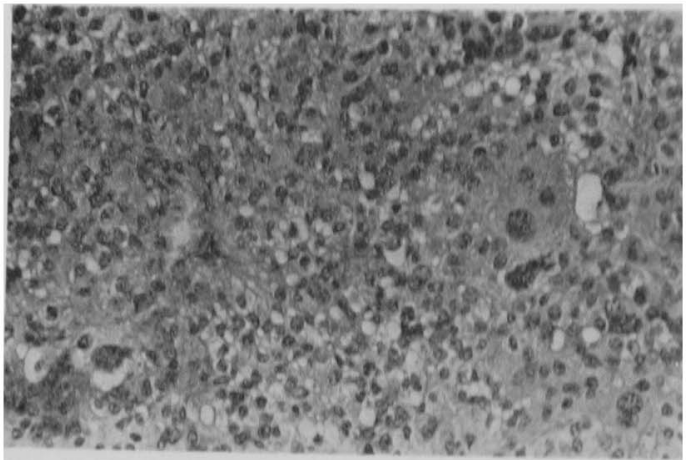

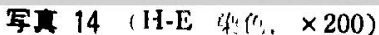

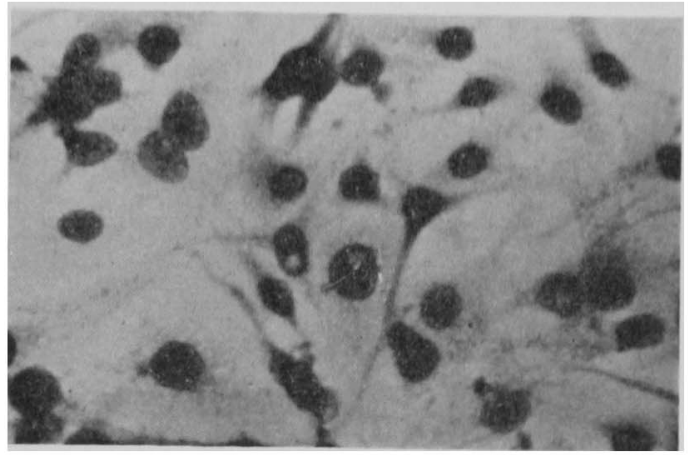

写重 16 (Jacobson 染色, ×200)

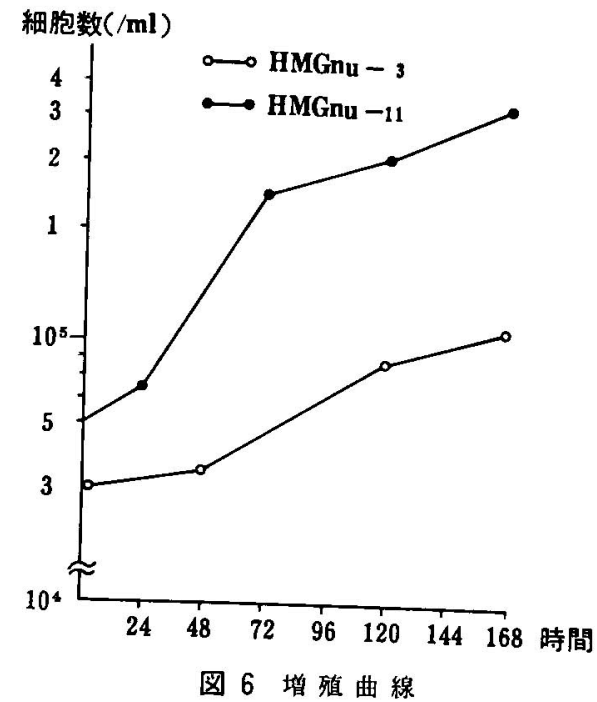

壊死が钼察された（写直13）。

(4) 形成腫瘍の形態観察

(1) 光顕所見

重序組織は粗な結合組織に被われて、ヌードマウス由 来の血管をとりこんでいる，尰瘍細胞汢細胞質にそしく

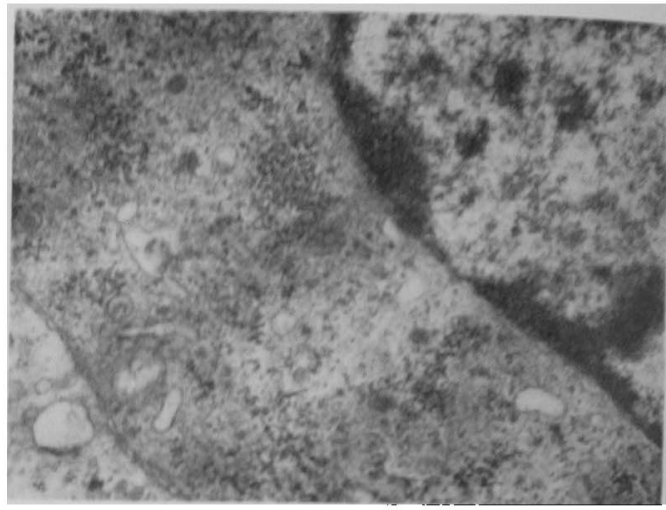

7月 15 . $(\times 20,000)$

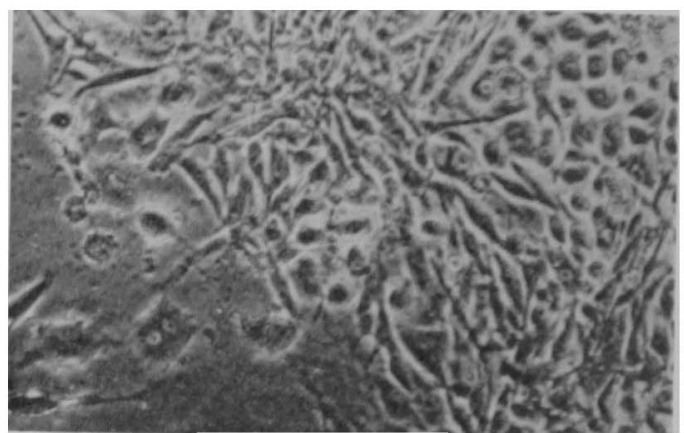

军查 17 位相差 $(\times 200)$

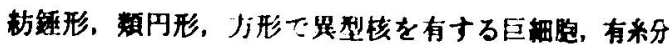

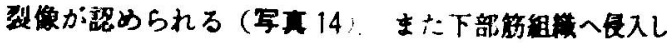
ている所見もみられ，amelanotic ではあるが原発篓中

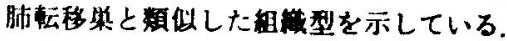

(2) 奄影所見

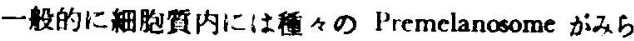

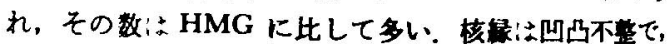
大きな仁を有しクロマチンの分布は不均等である（军真 15).

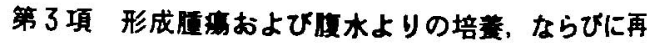
移植

（1）固型尰媓よりの培䖯所見

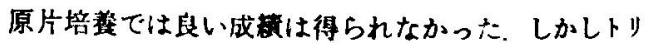
ブシンおよびマクネチックスターラーによる分散法で は，HMG に類似した所見が得られ，HMGに比して

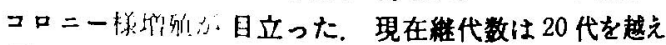
HMG にちなんて，HMGnu と命名した，写直16は HMGnu 6 代めの細胞で，核内に爸胞が涀察される。 图6はHMGnu 3 代および11代について重複培責し， 経時的変化を示したものである，3 代めは，48時間後 $4.4 \times 10^{4}$ 個, 120 時間後 $7.9 \times 10^{4}$ 個, 168 時間後 $10.1 \times$ $10^{4}$ 個，11代めは24時間後 $6.5 \times 10^{4}$ 個，72時間後 $11.5 \times$ 
$10^{4}$ 個， 168 時間後 $32.9 \times 10^{4}$ 個であり，それぞれ Doubling time は72時間, 79時間で，1週間の增殖度は HMG-R と類似している.

（2）腹水よりの培䖭所見

多角形，上皮様配列を有する 細胞が目立ち HMG 初 期に比して紀鏵形，樹枝状突起を有する細胞は少数であ った（写直17）。た上皮棣細胞で細胞資内にメラニン と思われる顆粒を多数含有する細胞す钼察されたが，継 代維持できなかった。

(3) HMGnu のヌードマウスへの移植

HMGnu-7 をヌードマウス 5 愊の背部皮下および変 貯内人 HMG 移植時之同数 $\left(1 \times 10^{6}\right.$ 個) 注入した，移 植後 6 週頃より四瘤の形成が㸾められ，HMG に比して 1 か月程早く，着床率は表 2 に示すごとく $100 \%$ である が腹水化はみられなかった。

\section{III. 総括および考寮}

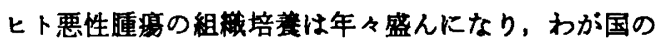
各施設で樹立維持されている七卜癌細胞培嗂細胞株 (リ ンバ芽球様細胞株を除くうだけです 149 株に達するとさ

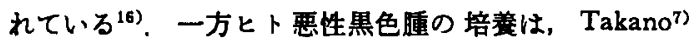
により1926年初めて，同種および異種血清が培㢣細胞に およぼす検討の一部として行われたすのですでにこの ときメラニンといら特異的マーカーを有することを理由 に，培羡上広籁な研究を行いらるとしている。

その後 Foley ら ${ }^{17)}$ の報告をはじめわが国では春日ら

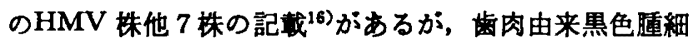
胞株についての報告は，著者の渉獑した限りでは見当た らない.

\section{1. 細胞株}

多くの報告で，細胞株あるいは細胞系などの用語が混 用されており，まず細胞株に関する一般的な概念との関 係から HMG について考察する。

山田 ${ }^{183}$ は，細胞株について日本語としての「株」は 「株化する」などのよらに培着内で無限增殖性を獾得し， その性質が一部です明らかとなって安定した培養細胞と なることを意味することが多く，他方で細胞株としての 特長づけの意味でも用いられ，米国組織培養学会(TCA) の cell strain (細胞株), cell line (細胞系) を区別しな いときは株として表現している。 また日本組織培養学会 の細胞株に関する規定によると年，細胞株 (established cell line）は少なくとす50代の継代または 1 年以上にわ たって增殖を維持した細胞としている。

樹立 (株化) (establishment) については，みかけ上 限りなく安定に增殖し続ける状態に達すること ${ }^{18)}$ とさ れ，この時期については不明確で，Fogh ${ }^{20)}$ とよれば経 験豊かな $2 \sim 3$ 人の cultrist が持続する発育能を有する と判定した時であり，明確な規定はできないとしてい
๖.

これらいくつかの苾淮はあるが, HMG は 2 年半以上

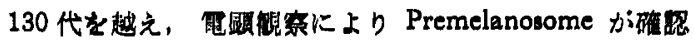

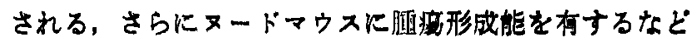

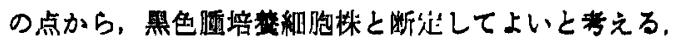
また TCA ${ }^{(8)}$ の定戥化従えば, continuous あるいは established melanoma cell line と表现しろるが, cell strain とは表現しがたい，

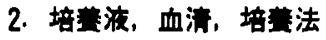

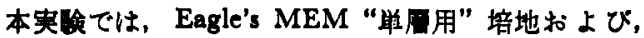
Moore ら"1)により白血病用として開発され，細胞自身 の增殖棣式を餉し，単展，浮遊培黄が可能であるとされ るRPMI 1640 の 2 梗を 2 代以降並行して使用した。 HMG は浮遊細胞系として增殖しなかったか，旋回培卷 に上る菒塊形成能，継代時にみられる培䓹瓶底面からの 剩離度, 継代に伴5 形的变化, Doubling time, ヌート マウス移植後の腹水化の可否さらに腹水よりの培萎所見 などを総合すると RPMI 1640 が Eagle’s MEM より も本来の形質を保持させていると考えられる、しかし

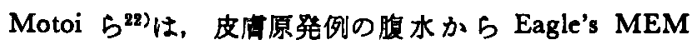
を使用し，付着性ではあるが，メラニン形成能を有する PL 14株を 200 代 4 年半にわたって継代維持しており， 分化形貿については，MEMは必ずしも保持し得ないと はいいがたい，今後も継代を続け他の培㢣液についても 增殖様式, 分化形質の保持あるい溌現につき恰討を加 える必要がある.

細胞培辇時, 少数例を除いて血清は必要不可欠である が，近年にみられる価格の上㫒，各ロット間，動物種や 年龄差による成很のばらつきなど多くの閴題点を有して

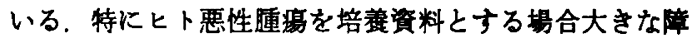
害となり，ヒト癌細胞培餈に有效な山根233のい5無血清 培地の開発が望まれる。

体細胞の分離培養法には，原片 (explant) 培錅法と細 胞分散法 (cell dispersion method) とがあり，培㟤材料 か十分かつ充実性で比較的軟らかい場合は分散法が有利 であるとされている．HMGにより形成されたヌードマ

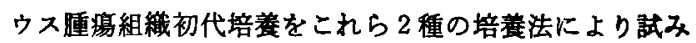
た結果, 細胞分散法で良好な成綨を得ている，原片培善 については, explant 材料の採取部位すなわちヌードマ ウスに形成される隀瘍の中心部の多くは壤死に陷ってい る点を十分認識して着手する必要があり，HMG では径 約 $2 \mathrm{~cm}$ を越えると壊死に陥る傾向にある.

\section{3. 細胞形態および色来形成能}

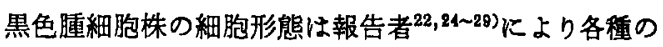
表現がされている。これらを総括すると，色素形成能の 有無により, 色素形成性 (melanotic), 無色素性 (amelanotic), 次いで細胞の配列様式，形態から上皮様 (epithelial), 線維芽細胞様 (fibroblastic), 円形 (round), 䊉鍾形 (spindle), 立方形 (cuboid), 三角形 (triangle) 


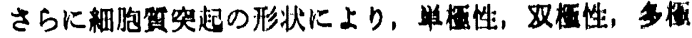
性 (uni-, bi-, multi-polar), 樹枝状 (dendritic) などの 用語が各程組み合わされている，HMG については初虰 には多角形，樹枝状を中心とした絸肘形然がるにれた

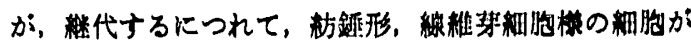
多数を占めるようになってきている。

細胞形態と分化能すなわちメラニン合成能について は, dendriticな細胞がタニン合成能が烸いとナる极

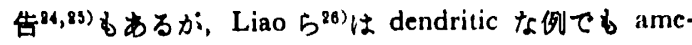
lanotic な场合むあるとしており, HMGです dendritic

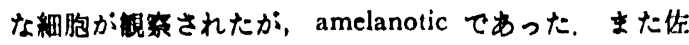

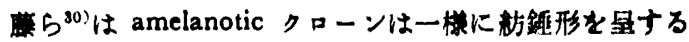

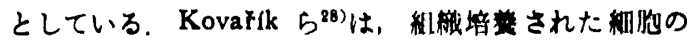

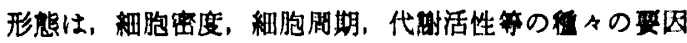
により変化を受けることを留意すべきであるとしてお り，細胞形態と機能発現については明確な結鲡は出な い.

色秦形成能に影䇾を与える因子として ACTH, MSH 等のホルモン, 紫外線, エックス線, 培㫫温度, 培地,

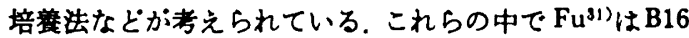
黒色腫培養細胞株に ACTH, MSH を低湌度 $(0.2 \sim 0.5$ $\mu \mathrm{g} / \mathrm{m} l)$ 作用させ，わずかなメラニン産生の增加，温度 $\left(4^{\circ} \mathrm{C}\right)$, 1-B-D-Arabinofranosyl, 寒天培地, 旋回培䇛 で促進を観察している．著者はHMG の旋回培䔞所見 で，Premelanosome の增加を钼察しており，これら各 種薬荗および要因を考虑したメラニン形成機棰の追求を 行う必要があると考えている。

\section{4. 電影所見}

melanocyte Kおけるチロシナーセ生成とメラニン生 成の場である Premelanosome とは独立した膜系におい ておのおの行われており，正常な場合この両者の協調が らまく行われて, Premelanosome 内にメラニンの形成 が進行していくと考えられている ${ }^{22)}$ このためDopa 反 応と Premelanosome 形成は必ずしる平行しない，Dopa 反広が陰性で amelanotic な場合は電䫒観察が診断上有

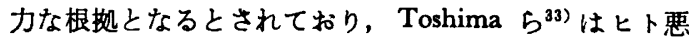
性黑色腫細胞株の amelanotic type について, Premelanosome の初期段階を越えないとしている，Maul ${ }^{34)}$ は 同様にヒト黒色腫の Premelanosome はジグザク状また は格子状蛋白粠造から鑑別しらると述へてている，HMG は amelanotic であり，細胞質内に Stage I〜II のPre. melanosome を認め melanocyte 由来であるとの診断根

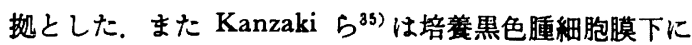
microfilament を観察し，SMMF と名づけて細胞分化 度との関連性を示唆しているが，HMG には認めていな い.

Epstein らにより Burkitt lymphoma の培養細胞中に 新しいヘルベスウィルス（EB ウィルス）が発見された ことは，ヒト癌ウィルス探索に方向性を与光，ヒト悪

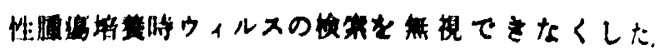

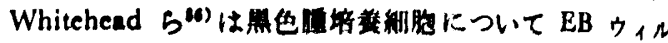
スを榆第し（一）てあったとしているが，HMGについ てる捡封を加えたいと教えている。

\section{5. 沓色体}

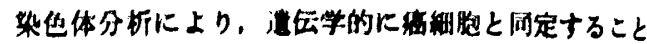

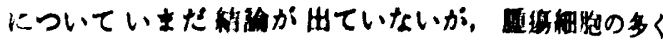

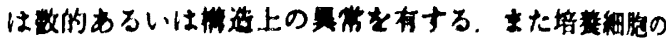

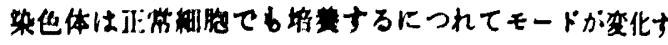

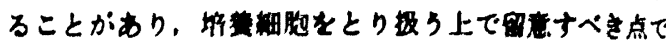

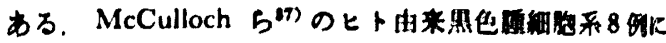
ついての怜期によれは、ををードは48〜87であり, 各秋 共通ナるマーカー架色体は路めていない，HMG の染色

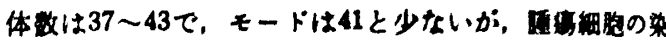

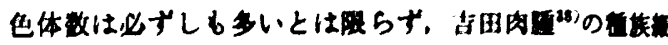
胸の婪色体数は40で正常の42よりる少ない。しかしヒト

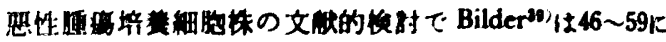
モードを有する国が多いとし，HMGのモード41は特做

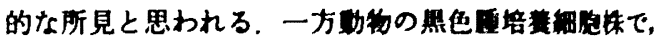
amelanotic クローンの染色体数は melanotic クローン に比して少ないとの告20)があり，HMG : amelanotic で染色体数が少ないなどの買似性があり舆味ある所見で ある. さらにマーカー染色体と思われる染色体かいくつ か見い出されているので，今後さらに领討する予定であ ろ.

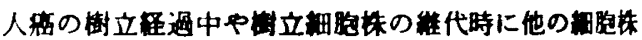
の混交が起こる危除性についての指接がある ${ }^{(0)}$. Muir

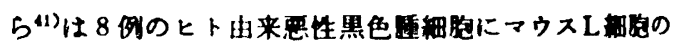
混交例を赫告し，同じ培器器内で培荄を行ったためであ ろらと述へている，なお HMG には架色体分析の结果 他の細胞の混入は畹めていない。

\section{6. ヌートマウスへの殗植}

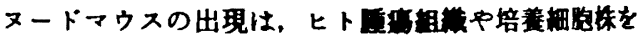
自由に逼時移植しかつ果代移植系として鹳持することを

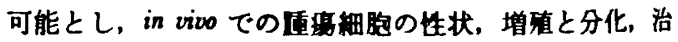

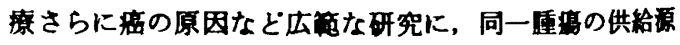
を保ち再現性のある実稄系を提供する点で画期的である といえる.

本研究における HMG のヌードマウス移植で，初期 には着床率は低値であった．しかし以啳の実涻では，䊒持 培爰液の差による相異はあったが高い值を示した。 また 組鐵像では，光顥的に amelanotic であるが，原発巣， 肺転移巣と類似した組變型を示し，in vilro では電影的 に継代に伴5脱分化がられたにもかかわらす，ヌート マウス移植により再分化が钼察された。このよらな長期 培誉細胞株のヌードマウス移植による再分化は，骨盾

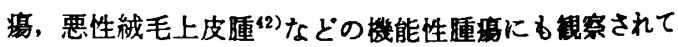
いる. 黑色腫培養細胞株については, 組織再構成のみが みられた例 ${ }^{(3)}$ ，元の組践よりる高い分化度を示した例 ${ }^{41}$ 


\section{の報告がある.}

ヌードマウスに移植された悪件聥瘦は，忶移形成や漫 潤増殖を起こさない45)とされていたが，墨色尰には呍移 する株や cachexyを起こして喢瘦死させる株む知られ ている ${ }^{43)}$. HMG では，転移形成は確認していないが, 移植下部筋組樴へ侵入している所見がみられた，SEKI 株では，移植後 1〜2遇め頃より著明な体重減少がみら れ， cachexyに楩ったと報告されている46)か， HMGで は果代移植後 3 週め頃に体重の一時減少が殷察され，ま た多くの場合移植後 1 週間から10日間の潘伏期があり， この時期になんらかの变化が起こっていると推察され ๖.

細胞株を移植後形成される嗹組織中の血管はヌード マウス由来と考えられ，尰䞍細胞には血管を新生させる 因子を有するとする説 ${ }^{47}$ と考えあわせると興味樑い。 HMG により形成される腫瘏周囲には血管系が良く発達 しており，各種実験ではこれらのことを考虑し，腫湯形 成部位，楽剂投与法，期間などを慎重に㭘討する必要が ある.

大星 ${ }^{42)}$ はヌードマウスに形成された腫場を再度培養し た場合, 成功率は高いとしており, 黑色腫細胞株につい て再培養し, Plating efficiency は元株より高いとする報 告すある ${ }^{48}$. HMGnu の培養経過は HMG と同様であ り, Doubling time は同じか幾分早い値を示している. 培養細胞は継代を重ねるにつれて，その多くは脱分化す ることが知られており, 細胞株を初期の培養状態にもと す点からもヌードマウスは有用である。

HMGnu を再移植した場合 HMG よりも着床が確認 されるまでの期間は短く, 成功率も高い。これは移植操 作，培着操作を繰り返すことにより，HMG 中の腫瘍形 成能の強い細胞の選択が行われていると考えられる。一 方累代移植により畽瘍形成能を失う例も知られている.

最近岡本ら ${ }^{49)}$ は皮庴原発の悪性黒色腫同一転移巣か $ら$, melanotic type と amelanotic type の 2 種のヌード マウス移植系を分離確立している.さらにこれらを応用 した治㞠実験で, DTIC は melanotic type の発育を完 全に阻止したが， amelanotic type については無効であ り, Melphalan がその発䏍を完全に阻止したと報告し ている. われわれの臨床例では DTIC を含む各種抗癌 剤を投与した結果, 原発巣の縮小と退色を認めたが，そ の後 amelanotic な腫瘤の増大が観察された. また剖検 所見です心臓を除く他の転移巣は amelanotic であり前 記治療実験との相関を示している.このことより加療に 際しては, melanotic, amelanotic か否かの臨床所見を 加味して慎重に対処する必要がある.

以上 HMG のヌードマウス移植により，腫瘍形成能 の確認，再分化，再培養による培着経過の再現，さらに HMGnu の再移植による腫瘍形成期間の短縮化が観察 された。

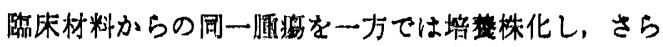

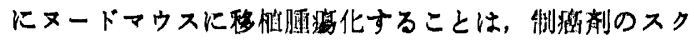
リーニングあいは投与法の梌村等, in vitro, in vivo で の各稓实駼を可能とし多くの知見をもたらすものと考え られる。

\section{V. 結綸}

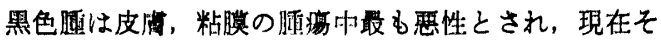
の症例数は增加している．落者は臨床材料より口腔粘膜 由来黑色連の in vitro の結論を得た。

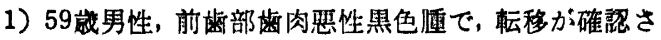
れた胸水中の細胞を培蓄し， 2 年半以上 130 数代にわた って継代維持し，株化樹立した．また本細胞株は，Eagle's MEM, RPMI 1640 の 2 種の培羡液で並行して維持し ており，10\% DMSO を加えて倲結保存可能である.

2) 本細胞株は原発組織, 位相差顕微鏡観察での増殖 様式等により嗹湯細胞と考えられる.

3）光学顕微鏡観察では，多角形，円形，紡銀形，樹 枝状突起を有する細胞から成り Dopa 反応, Combed Dopa-Premelanin 反応では（十）と判定できず, amelanotic である.

4) 電子顕微鏡 锤察では, Premelanosome が怹めら れ，黒色腫由来細胞であることが確認された。

5) Doubling time は, MEM 群 68.5時間 RPMI 群 50.0時間であった。

6) 染色体分析では，数は37〜43の範囲に分布してお り，モードは41を示し, マーカー染色体の存在が示唆さ れた.

7) 本細胞株をヒト宷肉由来悪性黑色腫培虫細胞株, Human Malignant Melanoma from Gingiva の頭文字 をとって HMG と命名する.

8）対照として外智および乳癌患者よりの胸水を資料 として培養を試みたが, 線維芽細胞様細胞が一部観察さ れたのみで，継代するに至らなかった，

9) HMGのヌードマウス移植により, 固型腫瘍化, 腹 水董湯化が認められ, 固型腫崵は現在累代 3 代に至って いるが，腹水系は果代できなかった。

10) HMG 移植後 $9 \sim 10$ 週で腫瘤形成が観察され, 累代では 2 ～ 3 週で認められる.

11）形成された腫湯は， amelanotic ではあるが原発 巣, 肺転移宩と類似の組織型を示す。また電影観察によ り Premelanosome が確認された。

12）培着液 RPMI 1640 と Eagle's MEM の 比較で は, (1) 継代に伴う形態变化, (2) 旋回培養での集塊形成 能, (3) ヌードマウス移植による腹水化の可否, (4) 増殖 能, (5) 継代時の細胞分散度などから RPMI 1640 の方 がより HMG の本来の形質を保持させることが示され 
た.

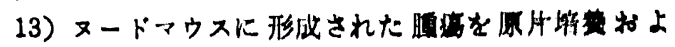

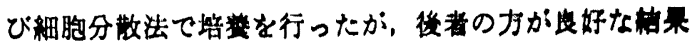
を得て找り，本紐胞系を HMG のヌードマウ久経由と いら意味で HMGnu と价名した。

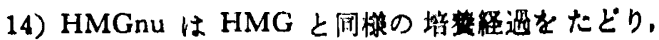

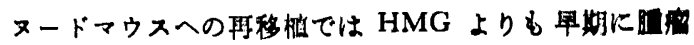
形成が覞察される。

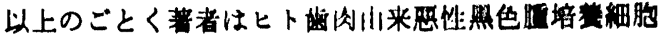

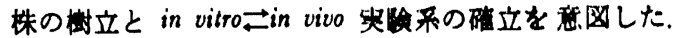

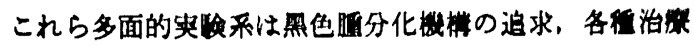
实诶に有用であると思了。

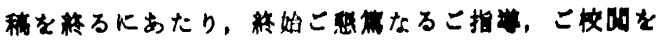

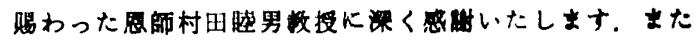

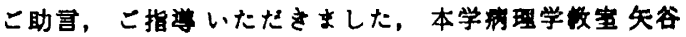

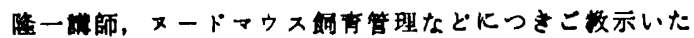

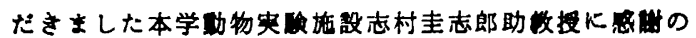
意を夷します。さららに本研究にこ協力いただいた本学口 腔外科学教室諸兄姉に深脚いたします。

本詥文の要旨の一部は第 24 回日本口腔外科学会総 会 (於名古屋), 第 34 回日本口腔科学会総会（於同山），第 7 回国際口腔外科学会（於 Dublin, Ireland)，第25回日 本口貯外科学会総会（於徳島）下おいて発表した。

\section{引用文 献}

1) Carrel, A., Burrow, M.T.: Cultivation in vitro of malignant tumors. J Exp Med 13: 571 1911.

2) Gey, G.O., et al.: Tissue culture studies of the proliferative capacity of cervical carcinoma and normal epithelium. Cancer Res 12: 264 1952.

3) Donald, J.G., et al.: In vitro cultivation of human tumors: Establishment of cell lines derived from a series of solid tumors. J Natl Cancer Inst 51: 14171973.

4) Flanagan, S.P.: "Nude," a new hairless gene with pleiotropic effects in the mouse. Genet Res Camb 8: 2951966.

5) Pantelouris, E.M.: Absence of thymus in a mouse mutant. Nature 217: 3701968.

6) Rygaard, J., Povlsen, C.O.: Heterotransplantation of a human malignant tumor to "Nude" mice. Acta Path Microbiol Scand 77: 758 1969.

7) Takano, Y.: Züchtungsversuche mit menschlichen Melanosarcom. Transact Jap Path Soci 19: 2621929.

8) Brown, M.M.L., et al.: Human oral malignant melanoma in cell culture. Cancer 19: 648
1966.

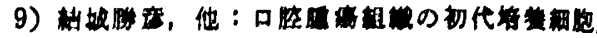
絊的娄 4:525 1978.

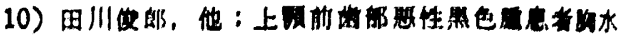

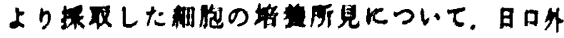
1t 27: 3311981 .

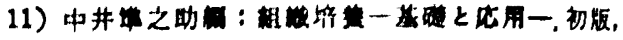

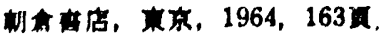

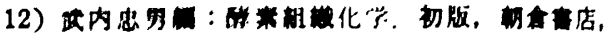
京，1974，166页。

13) Mishima, Y.: New technique for comprehensive demonstration of melanin, premelanin, and tyrosinase sites. J Inve Derm 34: 355 1960.

14) Overjera, A.A., et al.: Proceedings of the second international workshop on nude mice. 1 ed, Univensity of Tokyo Press, Tokyo, 1977, p 453.

15) Toda, K., Fitzpatrick, T.B.: Biology of normal and abnormal melanocytes. $1 \mathrm{ed}$, Univernity of Tokyo Press, Tokyo, 1971, p 277.

16）大星草一，他：日本で立維持されているとト

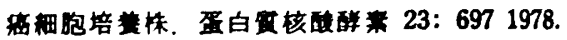

17) Foley, G.E., et al.: Isolation and serial propagation of malignant and normal cells in semi-defined media. Origins of CCRF cell lines. Cancer Res 20: 9301960.

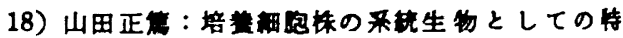
性. 組培鉒 6:75 1980 .

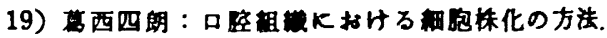
界展 43: 11301974.

20) Fogh, J.: Human tumor cells in vitro. 1 ed, Plenum Press, New York, 1975, p 123.

21) Moore, G.E., et al.: Culture of normal human leukocytes. JAMA 199: 5191967.

22) Motoi, M., et al.: A melanin-producing cell line derived from ascites of a patient with malignant melanoma. Gann 69: 1031978.

23）山根 ：組培篦の発展とその第20 回日本医学会会学街演要旨 1791979.

24) Cobb, J.P., et al.: Studies on human melanoma cells in tissue culture. I Growth characteristics and cytology. Cancer Res 20: 8581960.

25) Romsdahl, M.M., et al.: Establishment and biologic properties of human malignant melanoma cell lines grown in vitro. Surg Forum 18: 781967 .

26) Liao, S.K.: Characterization of human malignant melanoma cell lines. I. Morophology and growth characteristics in culture. J Nat Cancer Inst 54: 10371975.

27) Oizilbash, A.H., et al.: Characterization of human malignant melanoma cell lines. IV. Cytologic and histochemical characteristics. Acta Cytologica 21: 1471977. 
28) Kovařík, J., et al.: Establishment of cell line derived from human malignant melanoma. Neoplasma 25: 7011978.

29) Pope, J.H., et al.: Human malignant melanoma cell lines. Pathology 11: 1911979.

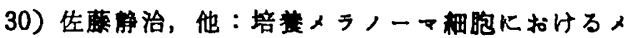

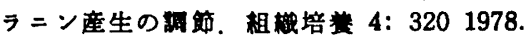

31) Hu, F.: Biology of normal and abnormal melanocytes. $1 \mathrm{ed}$, University of Tokyo Press, Tokyo, 1971, p 303.

32）小川和朗，他简：梱胞学大尔. 梱胞学各踚 7 ， 切版，朝會意店，東京，1978，250頁，

33) Toshima, S., et al.: Ultrastructure of human melanoma in cell culture. Electron microscopic studies. Cancer 21: 2021968.

34) Maul, G.G.: Golgi-melanosome relationship in human melanoma in vitro. $\mathrm{J}$ Ultrastruct Res 26: 1631969.

35) Kanzaki, T., et al.: Human malignant melanoma in vivo and in vitro. J Natl Cancer Inst 59: 7751977.

36) Whitehead, R.H., et al.: Tissue culture studies on human malignant melanoma. Pigment cell 1: 3821973.

37) McCulloch, P.B., et al.: Common and individually specific chromosomal characteristics of cultured human melanoma. Cancer Res 36: 3981976.

38）吉田俊秀：瘦㚼胞の染色体，棕合笽床 19：832 1970.

39) Bilder, J.L. : Human tumor cells in vitro. 1 ed, Plenum Press, New York, 1975, p 382.

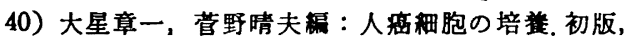

朝會害店，交京，1975，102面。

41) Muir, P.D., et al.: Contamination of human melanoma cell lines by mouse $\mathrm{L}$ cells. Pathology 9: 3011977.

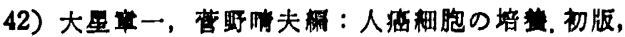
朝会害店，東京，1975，296而。

43) Kuga, N., et al.: Heterotransplantation of cultured human cancer cells and human cancer tissues into nude mice. Gann 66: 5471975.

44) Giovanella, B.C., et al.: Heterotransplantation of human malignant tumors in "Nude" thymusless mice. II. Malignant tumors induced by injection of cell cultures derived from human solid tumors. J Natl Cancer Inst 52: 9211974.

45) Povlsen, C.O., et al.: Heterotransplantation of human adeno carcinoma of the colon and rectum to the mouse mutant nude. Acta Path Microbiol Scand Section A 79: 1591971.

46) Kondo, Y., et al.: Proceedings of the second international workshop on nude mice. $1 \mathrm{ed}$, University of Tokyo Press, Tokyo, 1977, p 441.

47) Folkman, J., et al.: Isolation of a tumor factor responsible for angiogenesis. J Exp Med 133: 2751971.

48) Giovanella, B.C., et al.: Development of invasive tumors in the "Nude" mouse after injection of cultured human melanoma cells. J Natl Cancer Inst 48: 15311972.

49）岡本嘉六，他：ヒト悪性黑色腫の研究における ヌードマウス可移植連 (Endo 株)。禹と化学烄 法 7: 9311980 . 